\title{
Lessons From Washington and Colorado: The Potential Financial Gains of Recreational Marijuana to Canada
}

Nachshon Goltz

Ekaterina Bogdanov

Follow this and additional works at: https://scholarlycommons.law.case.edu/cuslj

Part of the Transnational Law Commons

\section{Recommended Citation}

Nachshon Goltz and Ekaterina Bogdanov, Lessons From Washington and Colorado: The Potential Financial Gains of Recreational Marijuana to Canada, 40 Can.-U.S. L.J. 126 (2016)

Available at: https://scholarlycommons.law.case.edu/cuslj/vol40/iss1/7

This Article is brought to you for free and open access by the Student Journals at Case Western Reserve University School of Law Scholarly Commons. It has been accepted for inclusion in Canada-United States Law Journal by an authorized administrator of Case Western Reserve University School of Law Scholarly Commons. 


\title{
LESSONS FROM WASHINGTON AND COLORADO: THE POTENTIAL FINANCIAL GAINS OF RECREATIONAL MARIJUANA TO CANADA
}

\begin{abstract}
Nachshon Goltz* and Ekaterina Bogdanov**
ABSTRACT: Canada lags behind jurisdictions such as Colorado and Washington in the legalization of recreational marijuana - but not in consumption. An empirical study conducted in downtown Toronto and studies by Statistics Canada reveal that marijuana use is widespread amongst Canadians, which suggests that the current regulatory regime is not effective as a deterrent. This paper details the results of the above-mentioned studies, reviews the regulatory framework of recreational marijuana use in Colorado, Washington, and Canada, and uses taxation data from Colorado to estimate the potential financial gain of marijuana legalization in Canada. The paper concludes with a brief discussion of the non-financial benefits of legalization. If you would like to smoke a joint, it will cost you about ten dollars in Denver. If it is your first time, you will also need to purchase a small reusable white bag for an additional two dollars. In Seattle, you do not need the bag, though the joint will cost you twice as much. In 2015, marijuana sales in Colorado almost reached the billion dollar mark $^{1}$ while in Washington State the sales reached 257 million dollars. ${ }^{2}$ In Toronto, a joint will cost you a 1000 dollar fine or six months in jail, or both. ${ }^{3}$ However, Canada's criminalization of recreational marijuana does not seem to be an effective deterrent, based on the smoking patterns of Canadians.
\end{abstract}

\footnotetext{
* PhD (Cand.), Osgoode Hall Law School; Editor In Chief, Global-Regulation.com

** JD/MBA (Cand.), Osgoode Hall Law School, Schulich School of Business

1 Ricardo Baca, Colorado Marijuana Sales Skyrocket to $\$ 996 M$ in 2015, The Cannabist STAFF (Feb. 9, 2016, 7:09 PM), http://www.thecannabist.co/2016/02/09/colorado-marijuanasales-2015-reach-996-million/47886/.

2 Jareen Imam, Pot money changing hearts in Washington, CNN (July 11, 2015, 11:21 AM), http://www.cnn.com/2015/07/10/us/washington-marijuana-70-million-tax-dollars/.

3 Controlled Drugs and Substances Act, S.C. 1996, c 19, ss 4(4), 5 (Can.).
} 


\section{TABLE OF CONTENTS}

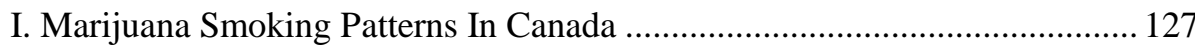

II. Regulatory Regimes in the United States ................................................. 129

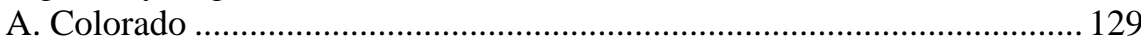

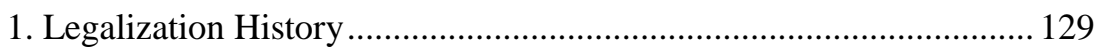

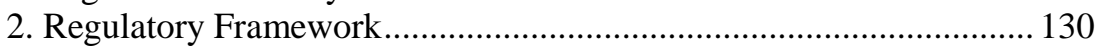

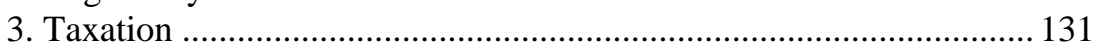

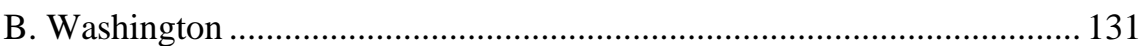

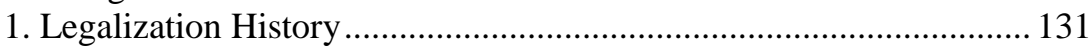

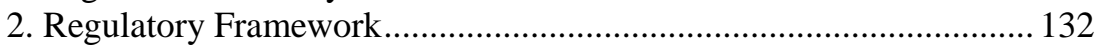

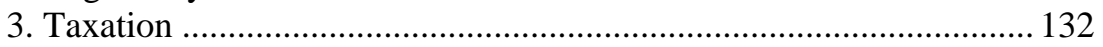

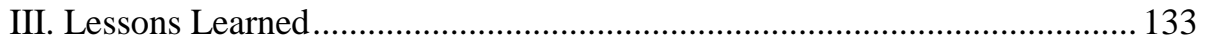

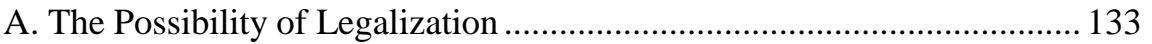

IV. The Financial Cost of Marijuana Criminalization ....................................... 134

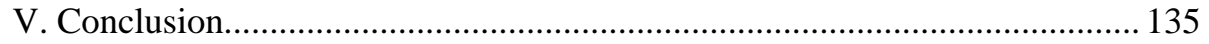

A. Other Costs of Marijuana Criminalization................................................ 136

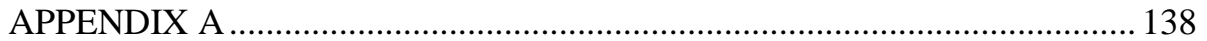

\section{MARIJUANA SMOKING PATTERNS IN CANADA}

Smoking marijuana is not a rare activity in Canada. According to Statistics Canada, in 2012, forty-three percent of Canadians reported that they used marijuana at least once in their life, while twelve percent used it in the past year. ${ }^{4}$ Of those who used marijuana in the past year, $94 \%$ had used it more than once. ${ }^{5}$ According to a study that this paper's authors conducted in Toronto, the average smoker is eighteen to thirty years of age, with a slight positive bias to males, people of color, and those originating from countries where marijuana smoking is more prevalent (e.g., Jamaica ${ }^{6}$ ). Males and cigarette smokers are more likely to be marijuana smokers, as well. Smoking marijuana is less common in more upscale neighborhoods, within mature populations and among young families. ${ }^{7}$

The authors' empirical study indicates that marijuana smoking is widespread in Toronto. According to the study, the estimated ratio of joints to cigarettes publicly smoked in the city is 1:25. More significantly, this revealed public attitudes to smoking marijuana: people are comfortable smoking in public at any

4 Michelle Rotermann \& Kellie LangLois, Prevalence and correlates of marijuana use in Canada, 2012, STATistics CANADA (Apr. 15, 2015) http://www.statcan.gc.ca/pub/82-003x/2015004/article/14158-eng.htm.

5 Id.

6 See Pete Brady, On Jamaica's ganja study, CAnNABIS Culture (Aug. 26, 2002), http://www.cannabisculture.com/content/2002/08/26/2407.

7 The research was done through identification and collection of marijuana rolled cigarettes butts, as well as counting regular tobacco cigarettes butts. This method was employed throughout downtown Toronto during three months. A trained dog was used to identify whether the buds includes traces of marijuana. In addition, observations were made in parks and other recreational facilities to identify marijuana smokers' characteristics. 
time of day and discarding their butts on the street, willing to risk facing a sanction from law enforcement or a measurably negative reaction from the general public.

Despite indications of widespread use of marijuana in Canada, it still remains illegal. Marijuana is derived from the marijuana plant, which is included in Schedule II of the Controlled Drugs and Substances Act ${ }^{8}$ ("CDS"). Accordingly, its possession, obtaining, and trafficking constitutes an offence under the CDS, with punishments of up to five years' imprisonment if indicted for possession or obtaining of the substance, ${ }^{9}$ and up to a life sentence if indicted for trafficking (lesser penalties are applicable to charges pertaining to smaller amounts of the substance and subject to summary conviction). ${ }^{10}$ The only exception is medical marijuana; its growth, sale, and use are governed by the Narcotic Control Regulations ${ }^{11}$ and Marihuana for Medical Purposes Regulations. ${ }^{12}$

Although the existing regulatory regime was fairly recently upheld by the Supreme Court of Canada (see $R v$ Malmo-Levine; $R v$ Caine),${ }^{13}$ and despite the resources devoted to prosecution by law enforcement, the frequency with which marijuana provisions are violated indicates that they fail as a deterrent, serving only to increase the cost and risk of the activity. This failure is increasingly recognized by various federal jurisdictions that have legalized, decriminalized or relaxed recreational marijuana use, including the countries of Colombia, Costa Rica, Czech Republic, ${ }^{14}$ Ecuador, the Netherlands, ${ }^{15}$ Portugal, Spain, Switzerland, Uruguay, Jamaica, Norway, Peru, Romania and Mexico, ${ }^{16}$ as well as the American states of Colorado, Washington, Oregon, ${ }^{17}$ and Alaska. ${ }^{18}$ In the cases of the District of Columbia ${ }^{19}$ and Maine's Portland ${ }^{20}$ and South Portland, ${ }^{21}$

8 Controlled Drugs and Substances Act, S.C. 1996, c 19 (Can.).

9 Id. $\mathrm{s} 4$.

10 Id. $\mathrm{s} 5$.

11 Narcotic Control Regulations, C.R.C, c 1041 (Can.).

12 Marihuana for Medical Purposes Regulations, SOR/2013-119 (Can.).

13 R. v. Malmo-Levine; R. v. Caine, [2003] 2003 SCC 74, 3 SCR 571 (Can.).

14 See Michael Knodt, The Czech Republic's liberal attitude towards cannabis is on rocky ground, SENSI SEEDS (July 15, 2014), http://sensiseeds.com/en/blog/czech-republics-liberalattitude-towards-cannabis-rocky-ground/.

15 Steve Rolles, Cannabis Policy in the Netherlands: Moving Forward Not Back, TRANSFORM DRUG POL'Y FOUND., https://www.unodc.org/documents/ungass2016/ Contributions/Civil/Transform-Drug-Policy-Foundation/Cannabis-policy-in-the-Netherlands. pdf (last visited Mar. 20, 2016).

16 See Emma Brant, Where in the World Can You Legally Smoke Cannabis? BRIT. BROADCASTING CORP. (Sept. 30, 2014), http://www.bbc.co.uk/newsbeat/article/29834450 /where-in-the-world-can-you-legally-smoke-cannabis.

17 Melanie Sevcenko, Two Months After Oregon Legalization, Pot Saturation Sends Profits up in Smoke, The GuARDiAn (Nov. 21, 2015), http://www.theguardian.com/usnews/2015/nov/21/oregon-cannabis-legalization-medical-marijuana-dying-market.

18 Greg Botelho, Alaska becomes latest state to legalize marijuana use, CABLE NEws NETwORK (Feb. 25, 2015), http://www.cnn.com/2015/02/24/us/alaska-marijuana/.

19 Rachel Witkin, High Hopes for D.C. Pot Growers as City, Congress Fight Over Law, NAT'L BROAdCASTING COMPANY (Sept. 12, 2015) http://www.nbcnews.com/storyline/legalpot/high-hopes-d-c-pot-growers-city-congress-fight-over-n 426046. 
it was municipalities that legalized use in each jurisdiction. Seven more U.S. states, Massachusetts, California, Missouri, Hawaii, Maine, Nevada and Ohio, are in the process of voting on permitting recreational marijuana. ${ }^{22}$

As these jurisdictions make the shift from criminalization to legalization and regulation, in recognition of the need to conserve law enforcement resources, enhance revenue, and promote individual freedom, the question of potential reform in Canada still looms large. This paper outlines the regimes which legalize and regulate recreational marijuana use and sale in the American states of Colorado and Washington, and explores the practical benefits that Canadians may derive from legalization, with a special emphasis on tax revenues. This paper does not address the morality of decriminalization.

\section{REGULATORY REGIMES IN THE UNITED STATES}

\section{A. Colorado}

\section{Legalization History}

Colorado legalized marijuana use in 2012, through Amendment 64 on section 16 of Article XVIII of the state's constitution..$^{23}$ The Amendment was passed subsequent to a referendum, "in the interest of the efficient use of law enforcement resources, enhancing revenue for public purposes, and individual freedom." ${ }^{24}$ It prescribed that marijuana is to be regulated "in a manner similar to alcohol," 25 with a resulting emphasis on (1) permitting use by persons aged twenty-one years or over, (2) implementing restrictions on driving while under the influence of $\mathrm{THC},{ }^{26}(3)$ the need for sales to occur through "legitimate, taxpaying business people, and not criminal actors," and (4) the need for further regulation to ensure that consumers are "informed and protected." 27 The section further permitted personal use of marijuana, including its possession, use, display, purchase, gift-giving, and transport in the amount of one ounce or less, and simultaneous growth of up to six plants, with three flowering at any given time. ${ }^{28}$ It allowed for marijuana cultivation, harvesting, processing, packaging,

20 Randy Billings, Portland police still issuing marijuana citations, despite legalization ordinance, PORTLAND PRESS HeRALD (Nov. 9, 2015), http://www.pressherald.com/2015/11/09/ police-still-issue-marijuana-citations-in-portland-where-small-amounts-are-legal-under-a-citylaw/.

20 Colo. Const. art. XVIII, $\$ 16$.

21 Gillian Graham, Pot legalization approved in South Portland, defeated in Lewiston, Portland Press Herald (Nov. 5, 2014), http://www.pressherald.com/2014/11/04/southportland-voters-support-legalizing-recreational-marijuana/.

22 Sam Becker, 7 States on the Verge of Marijuana Legalization, THE CHEAT SHEET (Oct. 15, 2015), http://www.cheatsheet.com/business/5-states-and-one-city-ready-to-legalizemarijuana.html/?a=viewall.

23 Colo. Const. art. XVIII, § 16.

24 Id. art. XVII, $\$ 16$ cl. (1)(a).

25 Id. art. XVIII, §16 cl. (1)(b).

26 Tetrahydrocannabinol, physiologically active compound of cannabis preparations.

27 Colo. Const. art. XVII, \$16 cl. 3(b).

28 Id. art. XVII, $\$ 16$ cl. 3(b). 
and sales by operators licensed under regulations to be adopted by July 1, 2013. ${ }^{29}$ The Colorado Retail Marijuana Code ${ }^{30}$ ("CRMC") became the governing statute.

\section{Regulatory Framework}

A comprehensive set of regulations under the CRMC, which established a licensing scheme for retail marijuana growers and retailers, as well as a set of controls for retail marijuana sales and cultivation, was made available on September 9, 2013 by the Marijuana Enforcement Division ("MED") of the Colorado Department of Revenue. ${ }^{31}$ The MED set out licensing procedures, security requirements, regulations of the retail process, as well as health and safety regulations, standards for cultivation and processing, and restrictions on advertising and display. The MED's evident regulatory priorities include: ${ }^{32}$

(1) Maintaining business legitimacy through criminal background checks for all owners, management, and staff, as well as denial of licenses to persons convicted of drug-related felonies within ten years (or any felony within five years) prior to the license application, or to persons with a criminal history indicating poor character;

(2) Preventing unregulated sales in Colorado and diversion of marijuana to states where its sale is illegal, by requiring that retail marijuana be obtained from licensed cultivation facilities, instituting protocols for storage, security (including locks and video-monitoring) and inventory tracking, prohibiting online sales, limiting the amount of marijuana that can be sold in one transaction, and requiring proof of Colorado residency before purchase;

(3) Protection of consumers by providing for the licensing and operation of Marijuana Testing Facilities to (optionally) test the product for contamination and potency, as well as requiring retail establishments to submit samples for testing by the MED on demand, instituting protocols for quality and potency testing, prescribing the content of product labels (which are to include information about the cultivation process), licenses, test results, health and use warning statements, and prohibiting the sale of nicotine or alcohol products at retail marijuana establishments;

(4) Prevention of diversion of marijuana to minors through requiring proof of age, prohibiting outdoor advertising, prohibiting marketing to an audience comprised of $30 \%$ or more minors, and requiring child-resistant packaging;

(5) Facilitation of a tax collection scheme, by requiring the maintenance of business records, and providing for the reporting and transmittal of taxes, as well as independent audit procedures.

29 Id. art. XVII, §16(4).

3012 Colo. ReV. STAT. § 12-43.4 (2014).

31 COlo. Code Regs. § 212-2 (2015).

32 See Colo. Dep't of Revenue, Laws: Constitution, Statutes and Regulations MARIJUANA ENFORCEMENT (2016). 


\section{Taxation}

Recreational retail marijuana in Colorado is subject to four separate taxes, instituted by various legal measures.

First is a fifteen percent excise tax on wholesale marijuana, collected by the State. The possibility of an excise tax was allowed for by Amendment 64 itself, which allowed a tax of up to fifteen percent. ${ }^{33}$ This tax rate, together with the above-described allocation to school construction, was approved by $65.27 \%$ of Colorado voters in a vote on "Proposition AA" under bill HB13-1318, which added Article 28.8 ("Taxes on Marijuana and Marijuana Products") to Title 39 of the Colorado Revised Statutes. ${ }^{34}$ The tax went into effect in January 2014. The first forty million dollars of annual revenues collected from the excise tax is allocated to the Public School Capital Construction Assistance Fund, and the rest is transferred to the Marijuana Cash Fund ("MCF"), used for purposes approved by the General Assembly. ${ }^{35}$ Approved purposes include funding the MED, expanding drug education and prevention efforts, and improving law enforcement.

Second, sales are subject to a ten percent state marijuana retail tax, also approved by Proposition AA under HB13-138 ${ }^{36}$ (this tax is to be decreased to eight percent as of July 1, 2017 $7^{37}$ ). Fifteen percent of the revenues are allocated to local governments, in proportion to the sales generated within their jurisdiction (in order to encourage the implementation of local zoning laws to allow for marijuana operations), and the rest is allocated to the MCF. ${ }^{38}$

Third is a state retail sales tax of general application, at the rate of $2.9 \%$. This tax is allocated to the general state cash fund. ${ }^{39}$

Fourth, retail marijuana sales are subject to all other generally applicable local taxes, allocated to local governments. As an example, Denver subjects retail marijuana sales to the general $3.65 \%$ sales tax which it imposes on all retail sales, as well as a special retail marijuana tax of $3.5 \%,{ }^{40}$ bringing the total taxation level in Denver to $35.05 \%$ (including the state excise and retail taxes).

\section{B. Washington}

\section{Legalization History}

Recreational marijuana use became legal in Washington State upon passage of "Initiative Measure No. 502," which amended various sections of Title 69

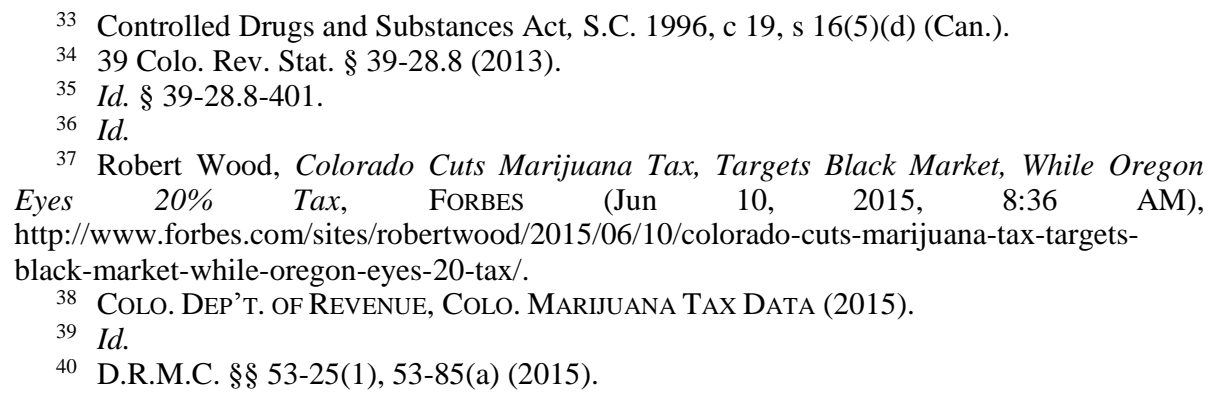


("Food, Drugs, Cosmetics and Poisons"41) and Title 46 ("Motor Vehicles"42) of the Revised Code of Washington ("RCW"). The stated purpose of the Initiative is substantially similar to the stated purpose of Colorado's constitutional amendments, and is to allow law enforcement to focus on violent and property crimes, to generate tax revenue, and to put marijuana sales in the hands of legitimate businesses instead of criminal organizations. ${ }^{43}$ The Initiative authorized the Washington State Liquor Board (now known as the Washington State Liquor and Cannabis Board, "WSLCB") "to regulate and tax marijuana for persons twenty-one years of age and older, and add a new threshold for driving under the influence of marijuana." 44 The WSLCB's regulations are contained in Chapter 55 of Title 314 of the Washington Administrative Code. ${ }^{45}$

\section{Regulatory Framework}

Washington State regulations evidence substantially the same priorities as those of Colorado, although its regime is more restrictive. In Washington State, cultivation of marijuana for personal use and gift-giving is prohibited, in any volume: marijuana may only be obtained from a licensed retailer. In Colorado, small amounts of marijuana may be grown, used and given away by an individual.

In Washington State, no marijuana producer or processor may also be a marijuana retailer, whereas a Colorado retailer may cultivate his/her own marijuana, provided the cultivation facility is also duly licensed. In addition, in Washington State retailers are unable to open stores or advertise within 1000 feet of schools, and 100 feet of public parks, libraries, arcades or other places frequented by minors, whereas no such restriction exists in Colorado.

In Washington State, marijuana products must be tested by a state-accredited independent facility prior to sale, whereas Colorado products can be tested by independent facilities at the option of the retailer, or by the MED on occasional demand. Finally, there are much more detailed regulations about the size and location of signage in Washington State, whereas Colorado retailers need only comply with local ordinances.

\section{Taxation}

Washington's marijuana taxation scheme was recently reformed through Bill 2136, passed on June 26, 2015. ${ }^{46}$ Even with this reform, which dramatically decreased taxation levels, Washington State has a more onerous taxation scheme than Colorado. Further to Bill 2136, Washington imposes a 37\% excise tax on marijuana at the point of sale,${ }^{47}$ with revenues allocated between a number of specific programs, including youth drug use prevention, healthcare, marijuana

$41 \quad 69$ R.C.W. $\S$ 69.50.325-369.

4246 R.C.W. $\S \S 46.61 .503-50571$.

43 Bill I-2465.1/11: Initiative No. 502 (2011), § 1.

44 Id.

45314 W.A.C. $§ 55$ (2015).

46 H.R. 2136 64th Leg, 2nd Sess. (Wash. 2015).

47 Id. $\S 205(1)(\mathrm{a})$. 
public health education, and program administration, evaluation, and research. ${ }^{48}$ The retail sale of recreational marijuana is also subject to general state and local sales taxes. In Seattle, for example, these general taxes come to $9.5 \%$, of which $6.5 \%$ goes to the Washington State, $2.6 \%$ to the City of Seattle, and $0.4 \%$ to the Regional Transit Authority. ${ }^{49}$

\section{LESSONS LEARNED}

\section{A. The Possibility of Legalization}

Public support for decriminalization of marijuana use is strong, with fiftythree percent of the population favoring decriminalization, thirty-five percent favoring legalization and taxation, and sixty-eight percent indicating that marijuana regulations ought to be relaxed in at least some form. ${ }^{50}$ Only about one-tenth of Canadians think that the current state of regulation is appropriate. ${ }^{51}$ Nonetheless, multiple bills calling for legalization have died over the years. ${ }^{52}$

In the recent election, Liberal leader Justin Trudeau made legalization a part of the Liberal party's platform. ${ }^{53}$ Similarly, NDP leader Tom Mulcair promised to decriminalize marijuana "the minute we form government." ${ }^{4}$ With the election of Justin Trudeau, it would appear that decriminalization at the federal level is now more likely than ever. Even if yet another decriminalization bill dies in the federal government, the American example suggests that provinces may opt to institute provincial regulatory regimes ${ }^{55}$ despite federal criminalization

48 A.C.L.U. OF WASH. ST., Estimated Annual Tax Distributions from I-502, https://acluwa.org/sites/default/files/pie_graph/502_tax_revenue_chart.pdf (last visited Mar. 20, 2016).

49 DeP'T of Revenue: WASH. St, State and Local Retail Sales Tax, http://dor.wa.gov/ content/fileandpaytaxes/fileoramendmyreturn/retailing/retailingact_statesalestax.aspx.

50 Lorne Bozinoff, Support for marijuana legalization steady at more than half, THE F. POLL (Aug. 20, 2015), http://poll.forumresearch.com/post/1362/just-one-tenth-think-currentlaws-are-appropriate.

${ }^{51} \mathrm{Id}$.

52 See C-38, 37th Parl., 2nd Sess. (2003) (on May 27, 2003, the Liberal government introduced a bill that would have decriminalized the possession for personal use of small amounts of cannabis. The bill's death was largely due to pressure from the American government's Drug Enforcement Administration, which had threatened to slow down bordercrossings along the Canadian-American border with increased searches for cannabis); See also C-17, 38th Parl., 1st Sess. (2004) (an identical bill was introduced in November 2004 by the minority Liberal government of Paul Martin, but it too died, when Martin's government was defeated in a confidence vote).

53 See LIBERAL PARTY OF CAN., Marijuana, https://www.liberal.ca/realchange/marijuana (last visited Mar. 20, 2016) ("We will legalize, regulate, and restrict access to marijuana").

54 Michael Bolen, Mulcair pledges NDP will decriminalize pot "the minute we form government”, CBC (Aug. 21, 2015, 5:06 PM), http://www.cbc.ca/news/politics/ndp-mulcairmarijuana-decriminalization-1.3199532.

55 Keith Leslie, Ontario Wants Marijuana Regulations Guidance From Federal Government, HUFFINGTON POST (Feb. 20, 2015, 12:54 PM), http://www.huffingtonpost.ca/ 2015/12/20/wynne-wants-clear-regulations-on-medical-and-recreational-marijuana_n_884830 6.html. 
(although a discussion of the legality and manner of such measures is beyond the scope of this paper). ${ }^{56}$

In any event, the provinces are well placed to enforce a new regime based on legalization and regulation of marijuana, whether it is federal or provincial in scope. Each of the Canadian provinces has a liquor board or commission, such as Ontario's Liquor Control Board of Ontario, which oversees alcohol sales in its jurisdiction. The Washington model of control, i.e. expansion of the liquor boards' existing powers, is a feasible option for all Canadian jurisdictions. As discussed below, legalization and regulation is an attractive alternative to the current state of affairs, especially financially.

\section{THE FINANCIAL COST OF MARIJUANA CRIMINALIZATION}

There is no denying that marijuana sales bring millions of dollars into the coffers of states and municipalities in which recreational use is legalized. So how much potential tax revenue is Canada, Ontario, and Toronto missing out on?

Consider: in 2014, the first year of legalized sales, Colorado retailers sold $\$ 213,414,440^{57}$ worth of recreational marijuana, before all taxes. ${ }^{58}$ According to the Substance Abuse and Mental Health Services Administration, approximately $15.09 \%$ of Colorado residents, ${ }^{59}$ or 808,220 people, smoke some amount of pot, resulting in average annual retail marijuana spending of $\$ 264$ per user. Extrapolated to Ontario, which is home to 1,331,299 marijuana smokers (12.1\% of the population), ${ }^{60}$ the first year of legalization could generate $\$ 351,462,936$ in marijuana sales province-wide, with $19 \%$ of this amount generated in Toronto (which comprises $\sim 19 \%$ of the province's population) ${ }^{61}$ Assuming taxation and tax revenue allocation at the level of Denver, Colorado and a simplified allocation of the Harmonized Sales Tax (HST), Table 1 describes what Canada, Ontario, and Toronto stand to lose on $\$ 351,462,936$ of annual marijuana sales. ${ }^{62}$

56 Canada's new Liberal government repeats promise to legalize marijuana, THE GuARDIAN (Dec. 4, 2015), http://www.theguardian.com/world/2015/dec/04/canada-newliberal-government-legalize-marijuana.

57 Calculated by dividing amount collected in $10 \%$ retail tax in 2014 by 10 , multiplying by 100.

58 COLO. DEP'T OF REVENUE, State of Colorado Marijuana Taxes, Licenses and Fees, Transfers and Distribution, December 2014 Sales Reported in January 2015, https://www. colorado.gov/pacific/sites/default/files/1214\%20Marijuana\%20Tax $\% 2 \mathrm{C} \% 20 \mathrm{License} \% 2 \mathrm{C} \% 20$ and $\% 20$ Fees\%20Report.pdf.

5917 stoner states: Where's marijuana use highest? CBS NEws, http://www.cbsnews.com/pictures/17-stoner-states-wheres-marijuana-use-highest/16/ (last visited Mar. 20, 2016).

60 Michael Bolen, Marijuana Use in Canada: Which Province Tokes The Most, THE HufFingTON Post (Sept. 20, 2013), http://www.huffingtonpost.ca/2013/09/20/marijuana-usecanada-stats-per-cent_n_3962841.html.

61 See Appendix A (for calculation details).

62 See Appendix B (for calculation details). 


\begin{tabular}{|l|l|}
\hline Jurisdiction & Estimated Revenues in First Year of Legal Sales \\
\hline Toronto & \$13.3 Million \\
\hline Ontario & \$110.7 Million \\
\hline Canada & \$17.6 Million \\
\hline
\end{tabular}

Table 1: Estimated Annual Revenues from Marijuana Sales in Toronto, Ontario, and Canada.

The values above would represent almost 5\% of the 2014 contribution of the City of Toronto to the budget of the Toronto District School Board ${ }^{63}$ and almost $0.25 \%$ of Ontario's 10-year transportation infrastructure investment. ${ }^{64}$ Although these amounts would not be decisive, these would be real funds, extracted from the underground economy and reaching cash-strapped schools and transportation authorities. Moreover, sales, and therefore tax revenues, increase as legalization becomes established. As an example, Colorado saw a $66.5 \%$ increase in marijuana taxes collected in December to June 2015, as compared to December to June $2014 .{ }^{65}$ This figure also does not include revenues from licensing fees, tourism from jurisdictions where marijuana is illegal, economic benefits in terms of employment in marijuana and marijuana-related industries, and cost savings to be generated by freeing up law enforcement resources, reduction in crime, and more. ${ }^{66}$ Finally, it must be noted that the administration of the regulatory regime is not costly relative to the revenues it generates, especially considering that administrative costs are relatively fixed even as sales increase. Washington, for example, allocates five million dollars to the WSLCB to administer the framework $;{ }^{67}$ relative to Canadian estimates above, this would represent only about $3.5 \%$ of all tax revenues. Higher taxation levels are also possible, though the optimal tax rate must be one which would not increase costs of legal marijuana to the point where users are driven to the black market for cheaper product.

\section{CONCLUSION}

Marijuana use is here to stay, whether or not it is criminalized. Faced with this state of affairs, a legalization/regulation regime modeled on the Colorado

63 Toronto Dist. School Bd. Consolidated Financial Statements of Toronto DISTRICT SCHOOL BOARD: AUGUST 31,2014, http://www.tdsb.on.ca/portals/0/aboutus/budget/toronto\%20district\%20school\%20board\%20\%20iar\%200814\%20(1-1216142151).pdf.

64 Ontario Ministry of Finance, Ontario Budget 2015: Building Ontario Up 2015 (2015).

65 COLO. DEP'T OF REVENUE, State of Colorado Marijuana Taxes, Licenses and Fees, Transfers and Distribution, July 2015 Sales Reported in August 2015, https://www. colorado.gov/pacific/sites/default/files/0615\%20Marijuana\%20Tax\%2C\%20License\%2C\%20 and $\% 20$ Fees $\% 20$ Report.pdf.

66 For simplification, the impact of the USD/CAD exchange rate is omitted.

67 Controlled Drugs and Substances Act, S.C. 1996, c 19, s16(5)(d) (Can.). 
and Washington experiences is neither unreasonable nor far-fetched. Legal, but tightly regulated, sales of marijuana could bring millions of dollars into municipal, provincial, and federal treasuries. A host of other benefits, still to be explored, will most likely emerge.

\section{A. Other Costs of Marijuana Criminalization}

Although data on the impact of legalization is still scarce given the extreme recentness of the regulatory change, the authors expect that the following additional benefits will also materialize:

- Reduction in crime (including violent and property crimes) associated with the trade in illicit drugs, ${ }^{68}$

- Diversion of revenue from criminal to legitimate organizations, which serves to financially cripple criminal organizations and reduce their capabilities across a range of activities; ${ }^{69}$

- Improved protection of marijuana users, as jurisdictions develop and perfect oversight, quality testing and consumer information mechanisms which are entirely non-existent when the substance is sold illegally $;^{70}$

68 See, e.g., Robert MacCoun \& Peter Reuter, Interpreting Dutch Cannabis Policy: Reasoning by Analogy in the Legalization Debate, 278 SCIENCE 47, 47-52 (1997); Robert G. Morris et al., The Effect of Medical Marijuana Laws on Crime: Evidence from State Panel Data, 1990-2006, Plos ONE 9(3): e92816 (Mar. 26, 2014), http://journals.plos.org/plosone/ article?id=10.1371/journal.pone.0092816; Magdalena Cerdá et al., Medical Marijuana Laws in 50 states: Investigating the Relationship Between State Legalization of Medical Marijuana and Marijuana use, abuse and dependence, 120 Drug AND Alcohol DePENDENCE 22, 22-27 (2012); Torill S. Ervik, Legalization of Medical Marijuana Reduces Crime, SCIENCENoRDIC (Mar. 18, 2015), http://sciencenordic.com/legalization-medical-marijuana-reduces-crime; Christia Sarich, Colorado Crime Rates Down $14.6 \%$ Since Legalizing Marijuana, http://naturalsociety.com/colorado-crime-rates-14-6-since-legalizing-marijuana/ (last visited Mar. 20, 2016); Erin Delmore, Study: Marijuana legalization doesn't increase crime, MSNBC (Apr. 15, 2014), http://www.msnbc.com/all/does-marijuana-lower-the-crime-rate; Paul Armentano, Violent Crime Drops Where People Have Access to Marijuana, Study Suggests, Alternet (Apr. 11, 2014), http://www.alternet.org/drugs/increased-access-cannabisassociated-reductions-violent-crimes.

69 See, e.g., Jeffrey A. Miron, The Budgetary Implications of Marijuana Prohibition, THE MARIJUANA POLICY Project 2005, http://www.cannabis-commerce.com/library/Miron_Report _2005.pdf; The Police Foundation \& The Colorado Association of Chiefs of Police, Colorado's Legalization of Marijuana and the Impact on Public Safety: A Practical Guide for Law http://www.nccpsafety.org/assets/files/library/Legalized_Marijuana_Practical_

Guide_for_Law_Enforcement.pdf; Rocky MounTAIN High INTENSITY DRUG TRAFFicking AREA, The Legalization of Marijuana in Colorado: The Impact (August 2014), http://www.in.gov/ipac/files/August_2014_Legalization_of_MJ_in_Colorado_the_Impact(1).p df; Beau Kilmer et al., Reducing Drug Trafficking Revenues and Violence in Mexico: Would Legalizing Marijuana in California Help?, INTERNATIONAL PROGRAMS AND

Drug POlicy ReSEARCh CENTER (2010), http://www.rand.org/content/dam/rand/pubs/ occasional_papers/2010/RAND_OP325.pdf.

70 See, e.g., D. Blake \& J Finlaw, Marijuana Legalization in Colorado: Learned Lessons, 8 HARV. L. \& POL'y REV. 359 (2014); APHA, Regulating Commercially Legalized Marijuana as a Public Health Priority, http://www.apha.org/policies-and-advocacy/public-health-policystatements/policy-database/2015/01/23/10/17/regulating-commercially-legalized-marijuanaas-a-public-health-priority; NPR, Quality-Testing Legal Marijuana: Strong But Not Always 
- Improved protection of minors, as the consumer base is tightly controlled through proof of age as well as retail location and advertising requirements of the kind already established in Washington and Colorado; $;^{71}$

- Promotion of healthier forms of consumption, such as edibles, which can replace the relatively more harmful joint - the predominant illegal form of consumption. ${ }^{72}$

- Greater social satisfaction with the state of regulation, which is less restrictive of personal autonomy when sales are legal and regulated, rather than criminalized.

Each of the above factors represents an avenue of future research, as empirical and other research data becomes available that would allow for tracing the impact of legalization and regulation on each area. As various regulatory regimes emerge, an analysis of best practices will also become possible.

Clean, NPR NEws (March 24, 2015, 11:22 AM), http://www.npr.org/sections/healthshots/2015/03/24/395065699/quality-testing-legal-marijuana-strong-but-not-always-clean; Christopher P. Edelson., Toward Rational Regulation of Marijuana in the United States: FDA's Role in Consumer Choice and Safety (1995 Third Year Paper), https://dash.harvard. edu/handle/1/8846750; Jonathan P. Caulkins et al., Considering Marijuana Legalization: Insights for Vermont and Other Jurisdictions, RAND CORP. (2015), http://www.rand.org/ pubs/research_reports/RR864.html; Mark A.R. Kleiman, Legal Commercial Cannabis Sales in Colorado and Washington: What can we Learn?, CENTER FOR 21ST CENTURY SECURITY AND INTELLIGENCE LATIN AMERICA INITIATIVE, http://www.globalinitiative.net/download/drugs/ north-america/Kleiman\%20\%20Wash\%20and\%20Co\%20final.pdf.

71 See, e.g., Johns Blomgberg School of Public Health, Keeping Legalized Marijuana Out of Hands of Kids, (2015), http://www.jhsph.edu/news/news-releases/2015/keepinglegalized-marijuana-out-of-hands-of-kids.html (last visited Mar. 20, 2016); Israel Amirav et al., Decriminalization of Cannabis - potential risks for children?, 100 ACTA PAEDIATRICA 618, 618-619 (2011); Brendan Saloner et al., Policy Strategies to Reduce Youth Recreational Marijuana Use, 135 PEDIATRICS (2015).

72 See, e.g., Rosalie L. Pacula et al., Developing Public Health Regulations for Marijuana: Lessons From Alcohol and Tobacco, 104 AM. J. OF Pub. Health 1021, 1021-1028 (2014); Tista Ghosh et al., The Public Health Framework of Legalized Marijuana in Colorado, 106 Am. J. OF Pub. Health 21, 21-27 (2016). 


\section{APPENDIX A}

\begin{tabular}{|c|c|c|}
\hline Line & $\begin{array}{l}\text { Line Description } \\
\text { \#Calculation Instructions }\end{array}$ & Number \\
\hline 1 & $\begin{array}{l}\text { 2014, 10\% Retail Marijuana Tax Collected, } \\
\text { Colorado } \\
\text { "From Colorado Marijuana Tax Data }\end{array}$ & $\$ 21,341,444$ \\
\hline 2 & $\begin{array}{l}\text { 2014 Retail Marijuana Before-Tax } \\
\text { Revenues, Colorado } \\
\#(1 / 10) * 100\end{array}$ & $\$ 213,414,440$ \\
\hline 3 & $\begin{array}{l}\text { Number of Colorado Marijuana Users } \\
\text { "State population*\% of Users; } \\
5,356,000 * 15.09 \%\end{array}$ & 808,220 \\
\hline 4 & $\begin{array}{l}\text { Annual Expense on Marijuana, per user } \\
{ }^{\#} \text { Line } 2 / \text { Line } 3\end{array}$ & $\$ 264$ \\
\hline 5 & $\begin{array}{l}\text { Number of Ontario Users } \\
\text { "Province population*\% of Users; } \\
13,600,000 * 12.01 \%\end{array}$ & $1,633,360$ \\
\hline 6 & $\begin{array}{l}\text { Torontonians as \% of Ontario Population } \\
{ }^{\#} \text { City Population/Province Population; } \\
\text { 2.615 Million/13.6 Million }\end{array}$ & $19.2 \%$ \\
\hline 7 & 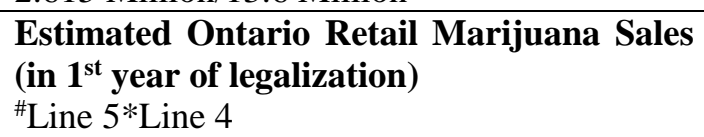 & $\$ 351,462,936$ \\
\hline
\end{tabular}




\begin{tabular}{|c|c|c|}
\hline Line & $\begin{array}{l}\text { Tax Type, \% (Calculation } \\
\text { Instructions) } \\
\text { \#Tax Allocation (\%) (Calculation } \\
\text { Instructions) }\end{array}$ & Annual Revenue (\$) \\
\hline 1 & Total Retail Revenues Before Tax & $\$ 351,462,936$ \\
\hline 2 & 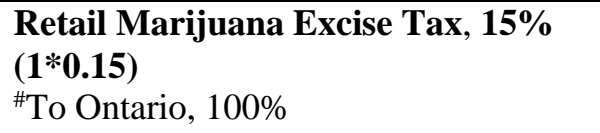 & $\$ 52,719,440$ \\
\hline 3 & $\begin{array}{l}\text { Retail Marijuana Sales Tax, 10\% } \\
(1 * 0.1)\end{array}$ & $\$ 35,146,294$ \\
\hline 4 & ${ }^{*}$ To Ontario, $85 \%(3 * 0.85)$ & $\$ 29,874,350$ \\
\hline 5 & ${ }^{\#}$ To Municipalities, $15 \%(3 * 0.15)$ & $\$ 5,271,944$ \\
\hline 6 & ${ }^{\text {\#To Toronto, } 19 \%\left(5^{*} 0.19\right)}$ & $\$ 1,001,669$ \\
\hline 7 & ${ }^{\# T}$ To other municipalities, $81 \%\left(5^{*} 0.81\right)$ & $\$ 4,270,275$ \\
\hline 8 & Harmonized Sales Tax, $13 \%(1 * 0.13)$ & $\$ 45,690,182$ \\
\hline 9 & "\#o Canada, $5 \%(1 * 0.05)$ & $\$ 17,573,146.80$ \\
\hline 10 & ${ }^{\#}$ To Ontario, $8 \%(1 * 0.08)$ & $\$ 28,117,035$ \\
\hline 11 & $\begin{array}{l}\text { Toronto Retail Marijuana Sales Tax, } \\
3.5 \%(1 * 0.035)\end{array}$ & $\$ 12,301,203$ \\
\hline 12 & Total to Toronto $(6+11)$ & $\$ 13,302,872$ \\
\hline 13 & Total to Ontario $(2+4+10)$ & $\$ 110,710,825$ \\
\hline 14 & Total to Canada (9) & $\$ 17,573,146$ \\
\hline 15 & Total to All Jurisdictions $(12+13+14)$ & $\$ 141,586,843$ \\
\hline
\end{tabular}

